\title{
The Great Depression and the current crisis: brand-related attitudes
}

\author{
Cosmin Ichim, „Al. I. Cuza” University of Iasi, Romania
}

\begin{abstract}
History should prevent us from repeating the mistakes of the past. This article focuses on the analysis and interpretation of the branding and promotion events that occurred during the Great Depression (1929-1933), projected on the decision of the marketing and management specialists of our times. The economic manifestations, such as: the unemployment rate, the decrease of the purchasing power, the crediting related difficulties, etc., specific to both periods of recession, revolve around the consumer and the way he modifies his consumer behavior. This paper tries to find an answer to the following question: given the decisions made by the managers in the 30's, what brand strategies are recommended for this period?

The answers to the question above are the object of the conclusions of this article. The recommendations provided herein invite us to meditate upon the depression from the previous century and to take a critical look at various marketing related attitudes, such as the disregard for rebranding or brand creation and the diminution of the promotion budgets.
\end{abstract}

\section{Keywords}

brand, brand strategies, the Great Depression, consumer behavior

\section{JEL Codes: M 31, M 37}

\section{Introduction}

In 1970, in his book entitled Future Shock, Alvin Toffler, in disagreement with the specialists of those times, who believed that science and technology were the main causes of the future product standardization, predicted that, with the passing of time, people would suffer because of a paralyzing excess of options, and not because a lack of products that one could choose from ${ }^{1}$. There are too many products, too many societies and too much marketing noise ${ }^{2}$. Consumer Digest magazine conducted a study which showed that a common family covers between 80 and $85 \%$ of its needs with the help of 150 products $^{3} .150$ brands - this is the new economy.

The brand has gained a crucial place in the history of marketing, for it has enabled us to make a distinction between various products and contributed to the creation of attitudes such as consumer trust and loyalty. Larry Light, a professional in the field of advertising, was interviewed by one of the editors of The Journal of Advertising Research about his predictions in relation to the development of marketing over the next three decades. Light's analysis proved to be very revealing: "The marketing battle will be a battle of brands, a

\footnotetext{
${ }^{1}$ Toffler, Alvin (1973), Şocul viitorului, Political Publishing, Bucharest, p. 248

2 Trout, Jack, Rivkin, Steve (2008), NOUA POZIȚIONARE. Cele mai noi informații despre strategia de business numărul unu în lume, Brandbuilders, Bucharest, p. 248

${ }^{3}$ Trout, Jack, Rivkin, Steve (2009), REPOSITIONING: Marketing in an Era of Competition, Change and Crisis, McGraw-Hill, p.179
} 
competition for brand dominance. Businesses and investors will recognize brands as the company's most valuable assets." ${ }^{4}$ and motivated me in writing this article.

This paper presents the brand in two different hypostases (the 1929 and the current crises) and identifies a series of common elements and differences that may help marketers who see the brand as an efficient weapon for communicating with the consumer and adjusting to their new consumer habits to make the best decisions.

After the analysis of the brand concept, I will position it in the two time periods discussed herein. This positioning will be strictly correlated with consumer behavior, for which purpose I will resort to case studies. Finally, I will try to give shape to a series of recommendations which have as a starting point the analyzed case studies.

\section{The brand as a concept}

The American Marketing Association defines the brand as a name, term, design, symbol, or any other feature that identifies one seller's good or service as distinct from those of other sellers ${ }^{5}$. According to the MacMillan dictionary, the brand has two meanings: a product or group of products that has its own name and is made by one particular company or a mark that is burnt onto the skin of an animal such as a cow, to show who owns it ${ }^{6}$.

The primary role of the brand is to generate trust, affection and loyalty. As cattle owners used to brand their cattle in order to know which ones are theirs, the companies will try, through the brand, to transfer, apart from the visual identity of the brand, values, attitudes and behaviors to the consumer's mind. Trust, affection and loyalty were measured with the help of the scale developed by Chaudhuri and Holbrook ${ }^{7}$. Trust was measured with the help of statements such as: I trust this brand, I rely on this brand, and affection through statements such as This brand makes me happy or This brand gives me pleasure. Two aspects of loyalty were taken into consideration: purchased loyalty (I will buy this brand the next time I will purchase this type of product, I intend to continue to by this product) and attitude-loyalty (I am addicted to this product, I am willing to pay more for this product). Numerous studies analyzed the relation between customer satisfaction and loyalty, starting from the premise that satisfaction plays a key role in explaining brand loyalty. Brand reputation, the influence of the group to which it belongs and recommendations are some other elements that contribute to obtaining loyalty. By winning the consumers' trust, affection and loyalty, companies can obtain significant advantages, such as: competitive advantage, increased profit margins, increased sales, fast market penetration, inexpensive extension of the product range.

\section{The brands of 1929}

The period 1922-1928 represented, for the American and European economies, a period of confidence and contentment with the outstanding results obtained, especially in industry. Economic development was accompanied by prosperity, salaries became bigger and bigger and unemployment almost disappeared. The crediting system facilitated the development of demand and, implicitly, of production. In his desire to increase productivity, imperatively necessary for augmenting demand, in his work entitled Principles of Scientific Management $(1911)^{8}$ Frederick W. Taylor stimulated the trend of scientific management, which advocated

\footnotetext{
${ }^{4}$ Aaker, David (2005), Managementul capitalului unui brand, Brandbuilders, Bucharest, p. V

${ }^{5}$ Kotler, Philip (2003), Marketing Management, Pearson Education, New Jersey, p. 406 6 *** (2006), MacMillan English Dictionary, MacMillan Publishing House, Oxford, p. 160

${ }^{7}$ Matzler, Kurt, Krauter S., Bidmon S. (2008), Risk aversion and brand loyalty: the mediating role of brand trust and brand affect, Journal of Product \& Brand Management, Vol. 17, Nr.3, pp. 154-162

${ }^{8}$ Nica, Panaite (2004), Management. Concepte şi aplicații practice, Sedcom Libris Publishing, Iaşi, p.13
} 
for production on assembly lines, with the strict timing of each operation. However, Taylorism enhanced fatigue and led to a decrease in the workers' technical creativity. The "robotizing" Taylorism was the source of the non-rationalization of consumer decisions.

Our consumer was more and more eager to consume, and, because of the normalization, typification and standardization principles applied to products and services, he would become loyal to the products he liked. Most marketing specialists argue that it is during this period that the packing and the brand start to act as information and pressure instruments on the buyer. They start to promote real or imaginary features of a given product or manufacturer. ${ }^{9}$ The exodus of the population to the city, in search for better paid jobs, accelerated urbanization; electrical appliances and the radio become part of the life of ordinary people. Mass-media infiltrates in society via the radio, newspapers, the cinema and even television, leading to the diversification of the communication channels and thus laying the foundations for many of the marketing principles and practices.

In contradiction with all the above mentioned aspects, on October 29, 1929 (the so-called black Thursday) people witnessed the shock of the fall of the share prices at the New York Stock Exchange. The Wall Street Crash was followed by a wave of bankruptcies, account withdrawals and insolvencies. The purchasing power suddenly dropped, companies significantly reduced their activity, and some of them even closed for good. The unemployment rate reached unimaginable values; where the employers kept their employees, they had to reduce their salaries. The product abundance faced a lack of buyers. The poverty caused by the lack of employment and by the diminution of the salaries led to large scale social movements: strikes and demonstrations of the unemployed, hunger marches, actions of the veterans, farmers, etc ${ }^{10}$.

I will proceed to the analysis of some brand related events, in strict correlation with the economic and social context presented above.

Rebranding. In 1930, Pepsi underwent a rebranding process and invested significant amounts for the promotion of the new image ${ }^{11}$, also supported by a new shape of the bottle. Coke Cola, its main competitor, invested primarily in repackaging and brought the six-pack on the market. Even if sales dropped, neither of these companies reduced promotion costs.

Reconstruction of the architecture of the brand portfolio. Ivory, the "99.44/100\% pure" floating soap and the first successful brand of Procter Gamble, resists the pressure of reducing promotion expenses and even manages to sponsor some of the first radio "soap operas", The O'Neills. Procter Gamble launches, also in this period, the Camay soup, unfortunately in the shadow of the Ivory brand. The company envisages, for the first time in its history, the creation of a brand management team, in charge of a marketing program and of its coordination with sales and production. This was a crucial event in the history of branding ${ }^{12}$.

Birth of a brand. In 1931, two years after he had lost his job with Steyr, because of the crisis, Ferdinand Porsche set up his own company, in Stuttgart. This would actually be the beginning of Porsche ${ }^{13}$. The first project dealt with the design of an average class car, but they subsequently returned to the idea of a popular car. Later, Ferdinand would manufacture a high speed vehicle that equaled the "Silver Arrows" during an age when German cars dominated Grand Prix races. A while later, Ferdinand faced new challenges: his car was supposed to carry two adults and three children at a speed of $100 \mathrm{~km} / \mathrm{h}$, to consume little

\footnotetext{
${ }^{9}$ Munteanu, Corneliu, Maxim, Emil, et. al. (2008), Marketing. Principii, practici, orizonturi, Sedcom Libris Publishing, Iasi, p. 14

$10 * * *$ (sine ano), The Great Depression and New Deal, 1929-1940s, Collin County Community College District, available at: http://iws.ccced.edu/kwilkison/Online1302home/20th\%20Century/DepressionNewDeal.html

11 Aaron, Perry (2009), Pepsi Logo Design Brief: Branding Lunacy to the Max, available at: http://www.fastcompany.com/blog/aaron-perry-zucker/new-ideas/pepsi-design-process-explained

12 Aaker, David (2005), Managementul capitalului unui brand, Brandbuilders, Bucharest, p. 5

${ }^{13}$ Albulescu, Matei (sine ano), Povestea unei pasiuni, Porsche Romania, Bucharest, p. 25
} 
fuel, not to have problems during the winter season and not to cost more than 990 Reich mark - a little more expensive then a motorcycle.

Innovation through creativity. Walt Disney stated: "I hope we never lose sight of one thing it was all started by a mouse." ${ }^{14}$ Mickey Mouse is the name of the first cartoon to have managed to synchronize sounds and image. When the crisis was the primary concern of the entire population, and all the politicians were preoccupied with their anti-crisis programs, Disney launched their first color animated cartoons. Nowadays this is one of the most powerful media and entertainment company in the world.

Non-interruption of the scheduled launches. In 1932, Chrysler launched the Plymouth model and sent a message that was considered, at that time, unorthodoxly honest. The message incorporated an image of Walter P. Chrysler, supporting his leg on the new Plymouth model, and the slogan: Look at all Three! ${ }^{I 5}$. Chrysler seemed to encourage the public to compare the new model with those of his competitors, Ford and General Motors, before making a decision. This kind of honesty led to record sales for the new model. Chevrolet also scheduled the launch of new models: Chevrolet AC (1929), AE Independence and $1 / 2$ Ton Pickup (1930). In his turn, Ford did not stay behind and launched, during the depression, Ford Model A (1929), Ford V-8 Model 18 (1932) and 20 other models.

1929. The end of the second wave of company mergers and purchases. After Ford had managed to become a vertically integrated company, being, via the purchase of companies, its own producers of tires and car bodies, General Motors ${ }^{16}$ embraced the same type of attitude; Colgate and Palmolive-Peet also decided to merge and to create the ColgatePalmolive-Peet Company brand.

Table. 1. Brands during the Great Depression

\begin{tabular}{|c|c|}
\hline Brand & Decisions during the Great Depression \\
\hline Pepsi & $\begin{array}{l}\text { Rebranding; repackaging; investments in } \\
\text { advertising }\end{array}$ \\
\hline Coca & repackaging, major advertising investments \\
\hline Procter \& Gamble & $\begin{array}{l}\text { Major advertising investments; reconstruction of } \\
\text { the product portfolio }\end{array}$ \\
\hline Porsche & Inspiration, opportunity, technical novelty \\
\hline Walt Disney & Birth of a brand by resorting to creativity \\
\hline Ford, Chrysler, Chevrolet & $\begin{array}{l}\text { Product launches, regardless of the economic } \\
\text { context, major advertising investments }\end{array}$ \\
\hline- & $\begin{array}{l}\text { The end of the second wave. Mergers or } \\
\text { purchases no longer take place }\end{array}$ \\
\hline
\end{tabular}

\section{Recommendations for the current crisis}

The social and economic context specific to the period of the Great Depression has many common aspects to the reactions to the current crises. Bankruptcies, account withdrawals, insolvencies, high unemployment rate and the decrease of the purchasing power characterize both analyzed periods. However, it is worth stressing the fact that our consumers did not reduce their expenses to zero; many of them started to thoroughly analyze what a product really has to offer. They started to seek those products that bring more value to the earned

\footnotetext{
${ }^{14}$ Grover, Ronald (2004), Walt Disney: He Built A Better Mouse, Business Week Magazine Online, 17 Mai 2004, available at: http://www.businessweek.com/magazine/content/04 20/b3883037_mz072.htm

${ }^{15}$ Tungate, Mark (2007), AdLand. A Global History of Advertising, Kogan Page, London, p. 33

${ }^{16}$ Romanek, Broc, et al. (2002), Mergers and Acquisitions, Capstone Publishing, Oxford, p. 15
} 
money. The brands that succeeded in doing this during the Great Depression gained loyalty, affection and long term trust.

The events which took place in the period 1929-1933, in association to the presented successful recipes, represented the basis for the recommendations below.

Do not put an end to investments in advertising. As you may notice in table 1 , the most frequently met decision of the companies during the Great Depression was to invest in the promotion of their own brand. We must not lose sight of the fact that, by resorting to a new brand, we strive to gain loyalty, affection and trust. If we reduce the marketing budgets, the consumers will feel abandoned and will reorient towards the products of the competition. If all the players in your field give up promotion, it is wise for you to be the only one that does not take such senseless measures. Thus, you will gain the long term loyalty of your customers.

Resort to advertising agencies or to specialists in the field. As the new consumer seeks to transform all purchases into a good deal, it is crucial for your sale process to achieve an efficient transformation of your message into perceived value. A flawed sale process will lead to wasted resources. Promotion campaigns, together with price decisions and promotion channels must be conceived in such a manner as to obtain the best possible results.

Rebranding. As we are dealing with a new type of consumer, with new consumer habits, we could try to adjust to this new reality by means of a new brand. It is absolutely necessary to question our consumer on the way he perceives our brand at present. Many of the current rebranding strategies focus on simplicity and clarity (for example, the rebranding of Pepsi, a strategy the company adopted during both period of recession, or Kosarom).

Reconstruction of the product portfolio. Say no to price discounts, focus on a new brand, and, implicitly, on a new product, depending on the positioning of the product in relation to its price. The luxury industry (or the industry of premium brands) has numerous rebranding opportunities; this is a strategic course, with beneficial effects as concerns the profit of a business, recommended for lowering a premium brand to an upper-medium or medium price level. It is worth mentioning that it is not advisable to return to high prices for the same brand. Consumers will focus on the average price segment and, consequently, this is where the battle between the producers will occur. The low segment does not have rebranding potential, since the consumers and the services in this segment are primarily motivated by the price and not by a potential emotional connection. A new brand, if it relies on innovation and on a potential need. We must keep in mind that recession comes with threats, as well as with opportunities. Ferdinand Porsche started his own business in 1929, when he became unemployed.

Cobranding (combination of the name of two or several brands), in case of takeovers or strategic alliances - this is the only solution for the brands subjected to mergers or acquisitions. Even if the Great Depression represented the end of the second wave in the history of mergers and acquisitions, the current crises showed us that some companies resorted to such strategies (see the cases of Caroli and Campofrio, which would become Caroli Foods Group, the taking over of Rompetrol by the Kazakhs and their desire to change the name of the fuel stations into Litro, powered by Rompetrol, the possible takeover of Zapp by Cosmote for the mobile Internet services owned by Zapp). Their decisions could not be more uninspired. The companies that resort to this type of strategies lose sight of the fact that this crisis will not last forever. For example, I wonder how Caroli and Campofrio will act when they see that the economic situation is back on the right track and they wish to be independent again. Acquisitions are recommended during this period, as they strengthen powerful companies and offer a chance to those that have not come with any solutions to the current crises. Anyhow, it is advisable to use cobranding in order to explain your customers what happened with their favorite brand and to aggressively promote the new identity. 


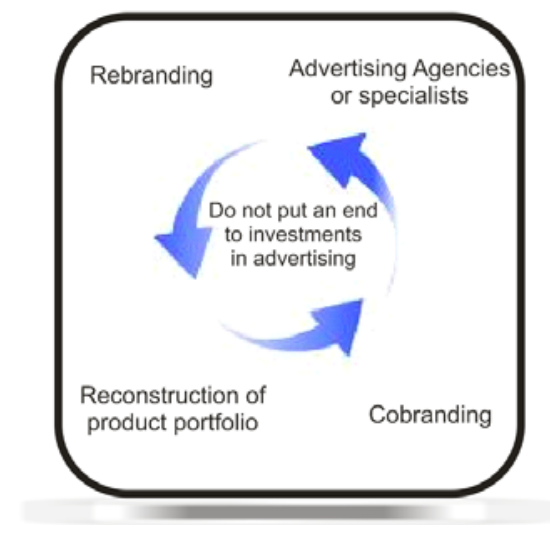

Figure. 1. Brand recommendations, suitable for times of recession

Our recommendations are primarily oriented towards those managers who, so far, have not seen the brand as an efficient weapon for communicating with the consumer. I hope that this article will stir the interest of managers and determine them to thoroughly analyze this phenomenon.

\section{Conclusions}

The lessons learned by those who experienced the Great Depression have already been successfully applied in the current economic and social environment. Nevertheless, this research has been limited by the historical positioning of marketing. We started from the premises that history repeats itself and that marketing is, after all, an ahistorical field ${ }^{17}$. Our recommendations are, however, purely subjective and strictly correlated to historical facts. They invite us to meditate upon the recession from the past century and to take a critical look at attitudes such as the disregard for rebranding or brand creation and the diminution of the promotion budgets.

\section{References}

1. *** (2006), MacMillan English Dictionary, MacMillan Publishing House, Oxford

2. *** (sine ano), The Great Depression and New Deal, 1929-1940s, Collin County Community College District, disponibil pe:

http://iws.ccced.edu/kwilkison/Online1302home/20th\%20Century/DepressionNewDeal.html

3. Aaker, David (2005), Managementul capitalului unui brand, Brandbuilders, Bucureşti

4. Aaker, David (2005), Managementul capitalului unui brand, Brandbuilders, Bucureşti

5. Aaron, Perry (2009), Pepsi Logo Design Brief: Branding Lunacy to the Max, disponibil pe http://www.fastcompany.com/blog/aaron-perry-zucker/new-ideas/pepsi-design-process-explained

6. Albulescu, Matei (sine ano), Povestea unei pasiuni, Porsche Romania, Bucureşti

7. Grover, Ronald (2004), Walt Disney: He Built A Better Mouse, Business Week Magazine Online, 17 Mai 2004, disponibil pe http://www.businessweek.com/magazine/content/04_20/b3883037_mz072.htm

8. Kotler, Philip (2003), Marketing Management, Pearson Education, New Jersey

9. Matzler, Kurt, Krauter S., Bidmon S. (2008), Risk aversion and brand loyalty: the mediating role of brand trust and brand affect, Journal of Product \& Brand Management, Vol. 17, Nr.3, pp. 154162

${ }^{17}$ Tadajevski, Mark (2009), Editing The History of Marketing Thought, Journal of Historical Research in Marketing, Vol. 1 No. 2, pp. 318-329 


\section{Studies and Scientific Researches - Economic Edition, no. 15, 2010}

10. Munteanu, Corneliu, Maxim, Emil, et. al. (2008), Marketing. Principii, practici, orizonturi, Ed. Sedcom Libris, Iasi

11. Nica, Panaite (2004), Management. Concepte şi aplicații practice, Ed. Sedcom Libris, Iași

12. Romanek, Broc, et al. (2002), Mergers and Acquisitions, Capstone Publishing, Oxford

13. Tadajevski, Mark (2009), Editing The History of Marketing Thought, Journal of Historical Research in Marketing, Vol. 1 No. 2, pp. 318-329

14. Toffler, Alvin (1973), Şocul viitorului, Editura Politica, Bucureşti

15. Trout, Jack, Rivkin, Steve (2008), NOUA POZIȚIONARE. Cele mai noi informații despre strategia de business numărul unu în lume, Brandbuilders, Bucureşti

16. Trout, Jack, Rivkin, Steve (2009), REPOSITIONING: Marketing in an Era of Competition, Change and Crisis, McGraw-Hill

17. Tungate, Mark (2007), AdLand. A Global History of Advertising, Kogan Page, London 